Cornell University Law School

Scholarship@Cornell Law: A Digital Repository

3-2011

The Limits of EU Hedge Fund Regulation

Dan Awrey

Follow this and additional works at: https://scholarship.law.cornell.edu/facpub

Part of the Banking and Finance Law Commons 


\title{
The limits of EU hedge fund regulation
}

\author{
DAN AWREY \\ Oxford University
}

This article examines the mechanics of the recently adopted EU Alternative Investment Fund Managers Directive. On balance, the results of this examination are not encouraging. The EU has failed to mount a persuasive case for why the Directive represents an improvement over existing national regulatory regimes or prevailing market practices in several key areas. Furthermore, by attempting to shoehorn an economically, strategically and operationally diverse population of financial institutions into a single, artificial class of regulated actors, the EU has established what is in many respects a conceptually muddled regulatory regime. Most importantly, however, the Directive's approach toward the amelioration of the potential systemic risks associated with alternative investment funds manifests an inherent and ultimately fatal structural flaw. This flaw punctuates the necessity of a globally co-ordinated response toward macro-prudential risks arising within a globally integrated financial system.

\section{A. Introduction}

On the surface, the global financial crisis of 2007-9 (the "GFC") has served to galvanise support for the proposition that we need to fundamentally rethink the ways in which we regulate financial markets and institutions. This consensus is reflected in the Communique released by G20 finance ministers and central bank governors following their summit in Seoul, South Korea on 11-12 November $2010 .{ }^{1}$ Prominent within this professed consensus is the conviction that we must strengthen public regulation and oversight of the so-called "shadow banking system": non-bank financial institutions including structured investment vehicles, money market funds and hedge funds. ${ }^{2}$ Dig a little deeper, however, and it is possible to detect emerging fault-lines between the AngloSaxon and Continental perspectives. Perhaps nowhere is this divergence of views more evident (or acute) than in connection with post-crisis regulatory reforms targeting hedge funds and other "alternative" investment vehicles.

This article examines the mechanics of the recently adopted Alternative Investment Fund Managers (AIFM) Directive $^{3}$ and offers some preliminary observations about its likely effectiveness. On balance, the results of this examination are not encouraging. First, the EU has failed to mount a persuasive case for why the Directive represents an improvement over existing national regulatory regimes or prevailing market practices in several key areas. Second, by attempting to ring-fence a disparate and essentially artificial class of financial institutions - as opposed to focusing on the various economic functions performed by these institutions, their operational models and the attendant risks - the Directive establishes what is in many respects a conceptually muddled regulatory regime. Untangling this morass is likely to preoccupy regulators and market participants well into the foreseeable future. Finally, and most importantly, the Directive's approach toward the amelioration of the potential systemic risks associated with alternative investment funds manifests an inherent and ultimately fatal structural flaw. It is this flaw which punctuates the necessity of translating the consensus embodied in the G20 Communiqué into a globally co-ordinated regulatory response.

\section{B. Hedge fund regulation: a reality check}

It can be difficult to cut through the rhetoric and demagoguery which surrounds the debate over the regulation of hedge funds, private equity funds and other alternative investment vehicles. Many observers view these institutions as mechanisms of market efficiency: providing greater diversification and liquidity, lowering market volatility and enhancing the process of price discovery. ${ }^{4}$ Others, however, view them as conduits for fraud and market manipulation and as sources of potential systemic risks. ${ }^{5}$ Some commentators herald them as would-be champions of more effective corporate governance. ${ }^{6}$ Some, meanwhile, condemn them as inherently short-termist ${ }^{7}$ or, somewhat more colourfully, as "hoodlums" 8 and "locusts". ${ }^{9}$ There is a broad perception that hedge funds were unregulated prior to the GFC. Yet, within the EU at least, this was demonstrably not the case..$^{10}$ There is also a widely held view that hedge funds are highly - if not excessively - leveraged. Again, empirical evidence perhaps suggests otherwise. ${ }^{11}$

So what do we know about hedge funds and other alternative investments? First, the universe of alternative investment funds encompasses a hugely diverse range of financial institutions engaged in a variety of different activities and posing very different prospective risks. Accordingly, there is likely to be no one-size-fits-all approach toward their regulation. Second, the risks posed by alternative investment funds are by no means unique to them. Proprietary trading desks, sovereign wealth funds, insurance companies and other 
institutional investors are frequently capable of playing similar roles within financial markets - and thus generating similar risks. Third, investors, counterparties and regulators require information respecting these funds and their managers in order to properly monitor these risks. ${ }^{12}$ Insofar as private market mechanisms prove ineffective in this regard, there exists a potential role for public regulation in terms of subsidising disclosure of this information and, more broadly, ensuring that these institutions implement appropriate policies and procedures respecting, inter alia, business conduct, governance and risk management. At the same time, however, more stringent regulation is not a panacea: Bear Stearns, Lehman Brothers and AIG were all heavily regulated. Finally, alternative investment funds were not a proximate cause of the GFC, ${ }^{13}$ nor have the substantial number of fund failures which have followed in its wake triggered systemic instability. That said, it would be foolish to disregard the possibility that these institutions - and hedge funds in particular - might be the catalysts of future systemic crises. ${ }^{14}$ It is within this complex and politically charged environment that the EU has introduced the AIFM Directive.

\section{The AIFM Directive: the basic mechanics}

The AIFM Directive introduces harmonised requirements for financial intermediaries engaged in the management and administration of alternative investment funds (AIFs) within the EU. The Directive (Article 3(a)) defines an AIF as any collective investment scheme which does not require authorisation under the Undertakings for Collective Investments in Transferable Securities (UCITS) Directive. ${ }^{15}$ This broad definition was designed to capture hedge funds, private equity funds, real estate funds and other institutional investment vehicles which had previously fallen outside the perimeter of EU financial regulation. ${ }^{16}$ Management and administration of AIFs are, subject to certain limited exceptions, reserved to EU-domiciled AIFMs authorised under the Directive. ${ }^{17}$

The Directive mandates that any AIFM seeking to manage or market an AIF within the EU obtain authorisation from the competent authorities in its home Member State. ${ }^{18}$ The Directive contains a de minimus exemption for managers which directly or indirectly manage AIF portfolios with total assets of less than $E 100 \mathrm{~m} .{ }^{19}$ This threshold is raised to E500m for managers which (i) only manage AIFs which do not employ any leverage, and (ii) do not grant investors redemption rights for at least five years from the date of a fund's inception. ${ }^{20}$ As a precondition to authorisation, an AIFM will be required to provide the competent authorities with detailed information respecting, inter alia, the identity of its owners, the characteristics of the AIFs it intends to manage, and any arrangements for the delegation of management functions and the valuation and safekeeping of portfolio assets. ${ }^{21}$ More broadly, an AIFM will be required to satisfy the competent authorities that it will be able to comply with the substantive requirements of the Directive. ${ }^{22}$ Once authorised, an AIFM will be permitted to provide management services to AIFs domiciled in any Member State ${ }^{23}$ and to market the securities of the AIFs it manages to "professional investors"24 across the EU. ${ }^{25}$ In the short term, this passport will only be available to EU-domiciled AIFs and AIFMs. It is presently contemplated, however, that the passport will be extended to non-EU-domiciled managers and funds in 2013. ${ }^{26}$

An AIFM authorised under the Directive must ensure compliance with substantive requirements respecting, inter alia, (1) conduct of business, governance and risk management, (2) third-party valuation and safekeeping, and (3) initial, periodic and event-driven disclosure to investors, the competent authorities and certain third-party stakeholders. The Directive also empowers the European Commission ${ }^{27}$ and, in exceptional circumstances, the competent authorities within each Member State, to restrict the use of leverage by AIFs.

\section{Conduct of business, governance and risk management requirements}

The Directive imposes uniform duties of care and loyalty on authorised AIFMs. Specifically, it mandates that an AIFM (i) act honestly, with due skill, care and diligence and fairly in conducting its activities, (ii) act in the best interests of the AIFs it manages, the investors in those AIFs and the integrity of the market, and (iii) ensure that all AIF investors are treated fairly. ${ }^{28}$ An AIFM must also take all reasonable steps to identify conflicts of interest ${ }^{29}$ and, thereafter, maintain and operate effective organisational and administrative arrangements with a view to preventing these conflicts from adversely affecting the interests of an AIF or its investors. ${ }^{30}$ Where an AIFM identifies a material conflict of interest within its operations - or where it determines that its conflict arrangements are not sufficient to ensure with reasonable confidence that the interests of AIF investors will not be adversely affected - it must disclose this fact to AIF investors. ${ }^{31}$

The Directive mandates that an AIFM implement risk management systems designed to measure and monitor all risks to which the AIFs it manages may be exposed by virtue of their investment strategies. ${ }^{32}$ This requirement contemplates, inter alia, (i) the implementation of an appropriate, documented and regularly updated due-diligence process for making investments, (ii) ensuring that risks can be accurately identified, measured and monitored through appropriate stress-testing procedures, (iii) ensuring that the risk profile of each AIF corresponds to its size, structure, investment strategies and objectives, ${ }^{33}$ and (iv) where an AIF engages in short selling, the implementation of procedures to manage the related risks. ${ }^{34}$ The Directive also requires an AIFM to implement systems designed to manage liquidity risk (ie ensure adequate liquidity matching) and to conduct regular stress tests of these systems under both normal and exceptional market conditions. ${ }^{35}$ It further requires the separation of portfolio and risk management functions - along with their respective review processes - within the operational environment of an AIFM. ${ }^{36}$ These risk management requirements are augmented by a requirement that an AIFM implement remuneration policies that are consistent with and promote sound risk management. ${ }^{37}$

Lastly, the Directive imposes modest initial and ongoing capital requirements. All AIFMs are required to maintain own funds of at least $€ 125,000 .{ }^{38}$ In addition, where the aggregate portfolio value of the AIFs it manages exceeds $€ 250 \mathrm{~m}$, an AIFM must set aside supplemental capital equal to 0.02 per 
cent of the amount by which the portfolio value exceeds the $€ 250 \mathrm{~m}$ threshold. Accordingly, for an AIF with a portfolio value of $€ 1 \mathrm{bn}$, an AIFM would be required to put aside capital totalling $€ 275,000$ (or 0.0275 per cent of aggregate portfolio value). These capital requirements are subject to any higher obligations imposed under Article 21 of the Capital Requirements Directive ${ }^{39}$ governing the capital adequacy of investment firms and credit institutions.

Perhaps not surprisingly given the broad nature of many of these requirements - to say nothing of the wide diversity of investment strategies, business models, conflicts of interest and other risks typically encountered in connection with different types of AIF - the Directive contemplates that the Commission will adopt level 2 implementing measures further specifying the precise substance of these requirements as they are intended to apply to each species of $\mathrm{AIF}^{40}$ Accordingly, it is in many respects too early to evaluate the precise impact of these requirements in terms of the day-to-day conduct and practices of AIFMs.

\section{Third-party valuation and safekeeping requirements}

The Directive requires that an AIFM appoint an independent third party to value both the portfolio assets of the AIFs it manages and their issued securities. ${ }^{41}$ This valuation exercise must be undertaken at least once a year and on each occasion on which securities of an AIF are issued or redeemed. ${ }^{42}$ An AIFM must also appoint a depositary for the purposes of, inter alia, (i) receiving subscription proceeds from AIF investors and depositing them into a segregated account, and (ii) safekeeping AIF portfolio assets. ${ }^{43}$ The depositary must be a credit institution having its registered office in the EU. ${ }^{44}$ The depositary is required to act independently and solely in the interests of AIF investors and will be liable to the AIFM and AIF investors for any losses suffered by them as a result of its failure to perform its obligations pursuant to the Directive. ${ }^{45}$

\section{Disclosure requirements}

The Directive lays down a series of initial, periodic and event-driven disclosure requirements designed to enhance the transparency of AIF activities to investors, the competent authorities and certain other stakeholder constituencies. An AIFM will be required to provide potential investors with, inter alia, a description of the relevant AIF's (i) investment strategy and objectives, ${ }^{46}$ (ii) valuation and redemption policies, (iii) valuation, custody, administration and risk management procedures, and (iv) fees, charges and expenses. ${ }^{47}$ Thereafter, an AIFM will be required to make available to investors on an annual basis an audited report containing the AIF's balance sheet, income statement, activity report and auditor's report. ${ }^{48}$ An AIFM must also submit these annual reports to the competent authorities in its home Member State. ${ }^{49}$

The Directive contemplates additional periodic disclosure to both investors and the competent authorities respecting (i) the percentage of AIF portfolio assets which are subject to special arrangements arising from their illiquid nature, (ii) any new arrangements for managing liquidity and (iii) the current risk profile of each AIF and the systems employed by the
AIFM to manage these risks. ${ }^{50}$ An AIFM will also be required to provide aggregated information to the competent authorities on a regular basis respecting the principal markets and instruments in which its AIFs trade, their principal exposures and important concentrations of risk. ${ }^{51}$ In addition, an AIFM must report to the competent authorities the main categories of assets in which its AIFs are invested and, where relevant, the use of short selling. ${ }^{52}$ The Directive contemplates that the Commission will adopt implementing measures which ensure that the nature and frequency of these periodic disclosures - or at least those targeted at investors - will be tailored to each species of AIF. ${ }^{53}$

Finally, the Directive imposes event-driven and subsequent periodic disclosure obligations on an AIFM in connection with the acquisition of a controlling interest in a company domiciled in the EU which employs more than 250 persons, has an annual turnover exceeding E50m and a balance sheet exceeding E43m. ${ }^{54}$ An AIFM will be deemed to have acquired a "controlling interest" if either it or any of the AIFs it manages holds, either individually or in the aggregate, 30 per cent or more of the voting rights of the target company. ${ }^{55}$ Where an AIFM acquires a controlling interest, it must make available to the company, its shareholders and employees (or their representatives) certain prescribed information. ${ }^{56}$ In addition, an AIFM must include in its annual report information pertaining to each company in which it holds a controlling interest. More specifically, the report must include information respecting, inter alia: (i) its operational and financial affairs, (ii) any financial risks associated with its capital structure, (iii) employee turnover, termination and recruitment and (iv) any significant divestment of assets. ${ }^{57}$

\section{Leverage requirements}

Last, but by no means least, the Directive empowers the Commission to set leverage requirements for AIFs where it deems them necessary to ensure the stability and integrity of the financial system. ${ }^{58}$ It further empowers national authorities to restrict the use of leverage in respect of individual AIFMs and AIFs in exceptional circumstances. ${ }^{59}$ The Directive mandates that an AIFM evaluate on a quarterly basis whether any of the AIFs it manages employ high levels of leverage on a systematic basis. ${ }^{60}$ An AIF will be deemed to have met this test where its combined leverage from all sources exceeds the value of its equity capital in two out of the past four quarters. ${ }^{61}$ Where an AIF exceeds this threshold, its manager must make prescribed disclosures to both AIF investors ${ }^{62}$ and the competent authorities in its home Member State. ${ }^{63}$

\section{The AIFM Directive: some preliminary observations}

There exists a theoretically strong informational argument in support of bringing many alternative investment funds and their managers within the perimeter of financial regulation. This argument is the strongest for hedge funds which, by and large, raise the most acute potential investor protection and market integrity problems and pose the greatest potential systemic risks. ${ }^{64}$ At the same time, there is obvious informa- 
tional utility in casting a somewhat broader net in recognition of the fact that institutions - and their attendant risks - can be expected to evolve over time. Direct public oversight of these institutions through authorisation and suitably tailored regulatory reporting requirements would provide competent authorities with information necessary to engage in more effective monitoring, and, ultimately, develop a better understanding of, among other matters, their evolving micro- and macro-prudential risk profiles. ${ }^{65}$ Enhanced disclosure to investors, meanwhile, would promote more informed contracting and, potentially, bring an end to questionable industry practices such as the provision of investor "side letters". ${ }^{66}$

What is ultimately unclear, however, is the extent to which the informational requirements embedded within the AIFM Directive will represent a marked improvement over existing national regulatory regimes or prevailing market practices. The issue here is not whether the Directive violates the principle of subsidiarity per se, but rather whether it is likely to have any real world impact. By way of illustration, the UK is home to the vast majority of EU-domiciled hedge fund managers. In total, the FSA oversees roughly 85 per cent of managers ${ }^{67}$ exercising discretion over approximately 80 per cent of European hedge fund assets. ${ }^{68}$ The FSA has long collected data from these managers in the context of its day-to-day supervisory activities and through thematic reviews, targeted surveys and non-supervisory dialogue. ${ }^{69}$ Simultaneously - and perhaps not surprisingly given the influence of sophisticated institutional investors on the demand side - the marketplace has exhibited some sensitivity to investor protection concerns as evidenced by, among other things, the voluntary provision of comprehensive pre-sale disclosure. The Alternative Investment Fund Management Association (AIFMA), for example, has developed a due-diligence questionnaire for prospective hedge fund investors which has purportedly become widely used within the industry. ${ }^{70}$ Ultimately, the effectiveness of these (and other) existing mechanisms for subsidising the production of potentially salient information undermines the practical case for pan-European regulatory intervention.

The EU has similarly failed to make a persuasive case for why the Directive will enhance conduct of business or risk-management practices. Once again, the FSA and other national regulators already impose conduct of business and risk-management requirements on authorised advisers and managers. Many of these institutions are also subject to the Capital Requirements Directive. EU regulatory intervention is rendered even less of an imperative by the fact that regulators in many of these jurisdictions - including the German Federal Ministry of Finance, ${ }^{71}$ a strong supporter of the AIFM Directive - have acknowledged the robustness of hedge fund risk management practices relative to those of other market participants. ${ }^{72}$ Indeed, that the hedge fund industry has developed relatively robust practices in this area should not come as a surprise: the high-powered incentives generated by the combination of a carried interest, ${ }^{73}$ managerial co-investment ${ }^{74}$ and the reputational market for investment management services make it in the economic interests of managers to design and implement effective safeguards against excessive risk-taking in the vast majority of circumstances. ${ }^{75}$
Proponents counter with the assertion that the AIFM Directive will ensure a harmonised approach toward disclosure, conduct of business and risk-management requirements. There are three relatively straightforward rejoinders to this argument. First, it is far from certain that harmonisation represents the optimal approach toward the regulation of financial markets or institutions. The primary source of uncertainty in this regard stems from the prospective, if empirically contestable, benefits of regulatory competition. ${ }^{76}$ Second, the EU's own Impact Assessment ${ }^{77}$ - the relevant portion of which, at three pages, might charitably be described as perfunctory ${ }^{78}$ - reveals no striking diversity of substantive approaches among Member States toward the regulation of alternative investments (and hedge funds in particular) but, rather, a broadly consistent one. ${ }^{79}$ What is more, as exemplified by the AIFMA due-diligence questionnaire, private mechanisms have already helped to promote a form of de facto harmonisation - and all without the bother or expense of direct regulatory intervention at the EU level. Third, and most importantly, harmonisation at the EU level is ultimately illusionary within the broader context of globally integrated financial markets. As examined in greater detail below, nowhere is this more readily apparent than in connection with the regulation of potential systemic risks.

A second overarching problem with the Directive stems from the decision to shoehorn an economically, strategically and operationally diverse population of financial institutions into a single, artificial class of regulated actors. This decision has opened the door to some potentially cumbersome (even nonsensical) rulemaking. The third-party valuation and safekeeping requirements provide a representative example. There exists a strong case in favour of imposing such requirements on institutions which (i) invest in relatively liquid assets (ie marketable securities), (ii) invest in markets with limited price transparency (ie over-the-counter derivatives markets) and/or (iii) provide investors with liquidity in circumstances not contingent on the prior realisation of portfolio assets. We might expect the majority of hedge funds, for example, to fall squarely into all three categories. In such circumstances, third-party valuation requirements would eliminate the conflict of interest arising where a manager compensated on the basis of assets under management exercises discretion over the valuation of investments for which there is no current, publicly available market price. ${ }^{80}$ Safekeeping requirements, meanwhile, would serve to mitigate custody risk: ringfencing client assets in the event of insolvency and thwarting Madoff-type frauds in which the opacity of an institution's investment activities - combined with the ease, speed and anonymity with which portfolio assets can be liquidated render it relatively straightforward for managers to make off with client money. ${ }^{81}$

It is far more difficult, however, to understand the rationale for imposing these requirements on, for example, private equity funds. The long-term, illiquid and typically very public nature of the investments made by these institutions virtually eliminates the potential for Madoff-type fraud. Put differently, the observability and verifiability of investment and divestment (and thus potential defection) to both investors and the marketplace provides an extremely powerful disincentive for would-be fraudsters. This practical constraint obviates much 
of the regulatory justification for placing the underlying assets - share certificates in private companies in this case - with a depositary. ${ }^{82}$ It is similarly difficult to identify the justification for third-party valuation requirements. As a starting point, arm's length valuators will invariably find themselves at a comparative disadvantage vis-ad-vis private equity firms in terms of the production and verification of salient information respecting the value of portfolio investments. This disadvantage is a function of both the general expertise possessed by private equity firms in evaluating the type of asset in question and, more importantly, their substantial asset-specific investments in due diligence and ongoing monitoring. More importantly, however, the mechanics of private equity funds eliminate the latent conflict of interest at the heart of the valuation problem. ${ }^{83}$ Specifically, distributions to investors are typically triggered by the disposition of portfolio investments (including via IPO) ${ }^{84}$ Investor liquidity is thus contingent upon prior disposition, which provides a credible (indeed, some might say definitive) third-party valuation of the asset. This link between investor liquidity and disposition also makes it difficult to understand how the liquidity risk management and related disclosure requirements set out in the Directive would apply to private equity funds (or, indeed, most other alternative investments). It is equally difficult to understand precisely what regulatory objectives the imposition of these requirements on such funds would ultimately serve. The Directive is, unfortunately, awash in such ambiguities.

The EU has conceded that many of the core provisions of the Directive will need to be tailored to reflect different species of alternative investment fund. Indeed, it has gone so far as to acknowledge - without offering any specifics - that some of these provisions may "make no sense" 85 for certain types of funds. It is the EU's view, however, that these more detailed, bespoke rules can and will be fleshed out in the process of formulating level 2 implementing measures, technical standards and guidelines. The EU anticipates this process will take up to two years. ${ }^{86}$ Here we find another curious policy choice. Citing the need to "proceed quickly" in response to the GFC, the EU dramatically curtailed its normal consultation processes in connection with the formulation of the Directive. ${ }^{87}$ Furthermore, at the time of this abridged consultation, the scope of the EU's proposal was expressly limited to hedge funds. Clearly, however, by electing to defer the articulation of many substantive requirements to the post-adoption rule-making phase, the EU has now effectively negated the potential benefits, if any, derived from a swift regulatory response. Simultaneously, by expediting the consultation process (and then dramatically expanding the scope of the Directive), EU regulators have failed to effectively leverage the vast wealth of available technical expertise - expertise that would have undoubtedly helped to resolve many of the issues with which they must now grapple. In the short term, wrestling with these technical issues will consume precious time and other resources. In the long term, and more broadly, the Directive's myopic focus on the object of regulatory intervention - rather than the objectives of it - seems an unlikely strategy for generating effective regulation.

Nowhere is the nearsightedness of the AIFM Directive more clearly reflected than in its approach toward the amel- ioration of potential systemic risks. ${ }^{88}$ There are at least four channels through which alternative investment funds could, theoretically, undermine financial stability. The first and most straightforward channel would be through the failure of a fund (or group of funds) which was itself systemically important. Second, the failure of a fund (or funds) could destabilise a systemically important financial institution connected to the fund(s) by virtue of its ownership, prime brokerage and/ or other counterparty relationships. ${ }^{89}$ Third, where a critical mass of funds coalesced to exploit the same opportunities within the same markets, simultaneous selling by these funds could - given the right circumstances - undermine market liquidity, exacerbate market volatility and, potentially, precipitate wider financial instability. ${ }^{90}$ Finally, the collapse of a fund (or funds) could trigger a forced liquidation of portfolio assets. ${ }^{91}$ Depending on the size of the liquidated positions relative to the liquidity of the underlying market, a disorderly "fire sale" could put significant downward pressure on prices - imposing substantial losses on (systemically important) counterparties and weakening the balance sheets of other (systemically important) financial institutions via mark-tomarket accounting requirements. ${ }^{92}$ However improbable, it is thus not inconceivable that the adverse effects of fund failure could reverberate throughout the global financial system.

The primary means by which the AIFM Directive attempts to address these risks is through the imposition of leverage constraints. Importantly, the EU is the only strategically significant jurisdiction to restrict the use of leverage by alternative investment funds. This includes the US - long home to the largest and most influential segment of the global alternative investment fund industry. ${ }^{93}$ Broadly speaking, the rationale behind leverage constraints is that they reduce the probability of fund failure - in effect by making funds less sensitive to market fluctuations and, thus, less susceptible to margin and/or collateral calls which might trigger a forced liquidation of portfolio assets. ${ }^{94}$ Implicit within this rationale is also the belief that - owing both to competitive forces within the prime brokerage industry and the status of financial stability as a public good - private counterparty credit risk management is unlikely to represent an effective response to potential systemic risks.

This logic is not necessarily incorrect - but it is incomplete. The key insight here is derived from understanding that the transmission of systemic risks through each of the channels described above is in no way impeded by geopolitical boundaries. In a world of globally integrated financial markets and institutions, the failure of a US hedge fund will have the same systemic impact as the failure of an otherwise similarly situated EU-domiciled fund. As a result, the EU cannot insulate itself from the systemic repercussions arising from the failure of an alternative investment fund operating outside the reach of the AIFM Directive. The EU thus faces a bleak calculus: while it will bear all of the direct and indirect costs of attempting to address systemic risks, the benefits thereby generated will be negligible insofar as it will remain exposed to negative externalities stemming from the failure or refusal of other jurisdictions to adopt equivalent measures. ${ }^{95}$ Simultaneously, any benefits will, at least in part, spillover to these other jurisdictions. Furthermore, relatively onerous leverage or other requirements serve to provide EU-domiciled managers with 
a marginal incentive to (re)locate their businesses offshore. ${ }^{96}$ From the perspective of the EU (or any other jurisdiction for that matter), systemic risk regulation thus represents a bundle of potentially significant costs without the realistic prospect of any corresponding benefits. It is for this reason that a globally coordinated response to potential systemic risks is not only desirable, but an imperative.

\section{E. Is the AIFM Directive a harbinger of things to come?}

The AIFM Directive was the product of a highly politicised process pitting the UK (and its substantial domestic financial services sector) against many of its Continental neighbours. ${ }^{97}$ This process played out in the context of a broader power shift within the EU away from national financial regulators such as the FSA and toward three newly created pan-European institutions: the European Banking Authority, the European Insurance and Occupational Pensions Authority and the European Securities and Markets Authority (ESMA). Brought into existence on 1 January 2011, it is ESMA which will ultimately be responsible for the administration of the Directive.

Understanding the Directive as the product of not only a policy process - but also a political one - serves to shed considerable light on many of its apparent shortcomings. For example, viewed from this perspective, the Directive can be understood not as a response to any perceived deficiency in existing national regulatory regimes or market practices but, alternatively, as an attempt to expand the scope of the EU's authority within the field of financial regulation. Similarly, the Directive's focus on the object of regulation, rather than its objectives, can be viewed as reflecting a desire on the part of some Member States - Germany and France key among them - to identify a suitable scapegoat for the excesses of Anglo-Saxon capitalism which they and many of their constituents perceive as having, among other things, precipitated the GFC. ${ }^{98}$ That these Member States had previously been unable to compete with the UK in the financial services sector made the economic calculus almost as straightforward as the political one. Finally, the EU's relatively aggressive stance in terms of the imposition of leverage constraints and other requirements can be viewed as a laudable (if ill-fated) attempt to influence the direction of international reforms designed

1 G20 Seoul Summit Leaders Declaration, 11-12 November 2010 ("G20 Communiqué"), available at http://www.g20. org/pub communiques.aspx (accessed on 26 January 2011).

2 Ibid,2. Other "shadow banks" include finance companies, assetbacked commercial paper conduits, securities lenders and, in the US, government-sponsored entities: see Z Pozsar,T Adrian, A Ashcraft and H Boesky, "Shadow Banking", Federal Reserve Bank of New York Staff Reports No 458 (July 2010).

3 The AIFM Directive ("the Directive") was voted through by the European Parliament on 11 November 2010. As of 26 January 2011, however, formal adoption had yet to be announced. The acronym AIFM is used to denote legal or natural persons whose regular business is to manage one or more AIFs (Directive, Art 3(b)). to mitigate systemic risks within the shadow banking sector. In each of these respects, it may ultimately not have been that EU policymakers had their heads in the sand so much as they were attempting to draw a line in it.

So is the AIFM Directive a harbinger of things to come? Potentially yes. The EU is already leading the charge to reform corporate governance and remuneration practices within financial institutions. ${ }^{99}$ It also recently announced its intention to crack down on speculation within commodities markets, which it views as having contributed to excessive volatility in food prices. ${ }^{100}$ Both of these initiatives have what might be characterised as a decidedly Continental flavour. Like the AIFM Directive, neither of them have been met with open arms outside the EU. If this emergent trend continues, the fragile consensus reflected in the G20 Communique will inevitability unravel. If it does, we will have failed to heed one of the most important lessons of the GFC.

\section{F. Conclusion}

It is in many respects still too early to pass definitive judgement on the AIFM Directive. The vast majority of its substantive requirements remain to be fleshed out through the articulation of level 2 implementing measures, technical standards and guidelines. The ESMA would be well advised to seek out and engage meaningfully with the alternative investment fund industry as part of this process. More broadly, it remains to be seen how the fledgling ESMA will grow into its new role as pan-European securities regulator. Will it soar on the wings of its substantial new powers? Or will it crash back down to earth under the weight of its broad remit and anemic resources? Despite this lingering uncertainty, it is possible to make two important, if cautious, observations. First, the real world benefits flowing from the adoption of the Directive are - at best - unclear. Many of its requirements will probably mirror existing national regulatory regimes and/or prevailing market practices. Others, meanwhile, and in particular those aimed at ameliorating potential systemic risks, are simply not fit for purpose. Second, the adoption of the Directive was likely motivated as much by politics as by policy. In the end, neither observation generates much cause for optimism.

Dan Awrey is University Lecturer in Law and Finance, and a Fellow of Linacre College, Oxford University.

4 See eg T Grabaravicius and F Dierick, "Hedge Funds and Their Implications for Financial Stability" (2005) European Central Bank Occasional Paper No 34, 5 and 25-26; Timothy Geithner, "Hedge Funds and Their Implications for the Financial System", Keynote Address at the National Conference on the Securities Industry (17 November 2004), and Staff Report of the US Securities and Exchange Commission (SEC), "Implications of the Growth of Hedge Funds" (September 2003) ("SEC Report").

5 For a good summary of the potential systemic risks posed by hedge funds, see N Boyson, C Stahel and R Stulz, "Hedge Fund Contagion and Liquidity Shocks" (2010) 65(5) Journal of Finance [forthcoming], and N Chan, M Getmansky, S Haas and A Lo, "Systemic Risk in Hedge Funds" in M Carey and 
R Stulz (eds), The Risks of Financial Institutions (University of Chicago Press, 2007).

6 See eg A Brav, W Jang, F Partnoy and R Thomas, "Hedge Fund Activism, Corporate Governance, and Firm Performance" (2008) 63(4) Journal of Finance 1729; M Kahan and E Rock, "Hedge Funds in Corporate Governance and Control" (2007) 155(5) University of Pennsylvania Law Review 1021; and T Briggs, "Corporate Governance and the New Hedge Fund Activism" (2007) 32 Journal of Corporate Law 681.

7 See eg the comments of veteran Wall Street lawyer Marty Lipton in "Shareholder Democracy: Battling for Corporate America", The Economist 9 March 2006.

8 See "Hedge Fund Rules Defended by French MEP", Financial Times 16 May 2010, quoting French MEP Jean-Paul Gauzès.

9 See "The Day of the Locusts", Time 15 May 2005, quoting Germany politician Franz Müntefering.

10 In the UK, for example, which is home to the vast majority of EU-domiciled hedge fund managers, these institutions typically require authorisation as investment managers and/or advisers under Arts 37 and/or 53, respectively, of the Regulated Activities Order promulgated under the Financial Services and Markets Act (2000), c 8 (FSMA). Once authorised, these managers/advisers are subject to, inter alia, the FSA's senior management arrangement, systems and controls and conduct of business rules for dealers and managers and relevant EU regulation including the Markets in Financial Instruments Directive (2008/10/EC) (MiFID), the Transparency Directive (2004/109/EC) and the Market Abuse Directive (2004/72/ EC). That said, the funds themselves and their administrators typically reside offshore. For a more detailed overview of the FSA's pre-GFC regulation of hedge funds, see FSA, "Hedge Funds: A Discussion of Risk and Regulatory Engagement", Discussion Paper 05/4 (June 2005) ("FSA Discussion Paper").

11 Recent estimates of average hedge fund leverage have ranged from 1.3 to 3.9 times equity; see HM Treasury, Comment Letter in Response to the Commission Services Consultation Paper on Hedge Funds (12 March 2009) (“Treasury Letter"); Alternative Investment Fund Management Association, Comment Letter in Response to the Commission Services Consultation Paper on Hedge Funds (30 January 2009), and H Shadab, "The Law and Economics of Hedge Funds" (2009) 6(2) Berkeley Business Law Journal 240, 254, citing various studies. By way of comparison, a US congressional oversight panel recently estimated the average leverage ratio of institutions across the entire financial system at 12 times equity; Congressional Oversight Panel, "Special Report on Regulatory Reform" (January 2009), 24. Unfortunately, the Panel chose to lump brokerdealers (historically the most leveraged financial institutions) and hedge funds into a single category for the purpose of its calculations. Utilising the TASS database, Grabaravicius and Dierick found that, as of 30 June $2005,32 \%$ of hedge funds employed no leverage, while only $13 \%$ employed leverage of greater than 1 times equity; Grabaravicius and Dierick supra $\mathrm{n}$ 4,31 . Notably, $23 \%$ of funds with assets of more than US $\$ 1 \mathrm{bn}$ employed leverage in excess of this threshold (ibid). Ultimately, however, estimating hedge fund leverage is difficult owing to both (i) a relative dearth of publicly available data, and (ii) the absence of methodological consistency in terms of how leverage is measured and reported.

12 A Lo, "Hedge Funds, Systemic Risk, and the Financial Crisis of 2007-2008", Written Testimony prepared for the US House of Representatives Committee on Oversight and Government Reform (13 November 2008), 3, and SEC Report at $x-x i$ and $78-80$.

13 See H Sants, Chief Executive of the FSA, speech delivered at Hedge 2008 (22 October 2008).
14 As outlined in Part D, these systemic risks could theoretically be transmitted through several channels, some of which are more likely to materialise than others.

15 2009/65/EC.

16 Directive on Alternative Investment Fund Managers (AIFMD): Frequently Asked Questions, Memo/10/572 (11 November 2010) ("FAQs"). The breadth of this definition is curtailed somewhat by a number of exceptions. Specifically, the Directive does not apply to collective investment schemes regulated under the UCITS Directive, EU credit institutions, pension funds, life assurance or reinsurance companies or sovereign wealth funds (Art 2, s 2(c)-(g)). The Directive also does not apply to an AIFM established in the EU but which does not provide management services to an AIF domiciled or marketed in the EU (Art 2, s 2(b)). Which is not to say, however, that these institutions fell outside the perimeter of regulation in their home Member States.

17 The Directive contemplates the delegation of administration (but not management) functions to offshore entities where (i) the third party is authorised to provide such services or is registered in the third country and subject to prudential supervision; (ii) there is an appropriate cooperation agreement between the competent authority of the AIFM and the supervisory authority of the third party; and (iii) the procedural requirements of the Directive relating to the delegation of functions are fulfilled (Arts 18 and 36).

18 Art 4, s 1.An AIFM may be authorised to provide management services in respect of all or only certain types of AIF (Art 4,s 2).

19 Art 2, s 2(a). There is a potential ambiguity in the English language version of the Directive respecting whether the thresholds apply at the fund or manager levels. The Commission estimates that the $\mathrm{E} 100 \mathrm{~m}$ threshold will capture $30 \%$ of all hedge fund managers (managing almost $90 \%$ of assets) of EU-domiciled hedge funds: Proposal for a Directive on Alternative Investment Funds, 2009/0064 (30 April 2009) ("AIFM Proposal"), 6.

${ }^{20} \operatorname{Art} 2$, s 2(a).

21 Art 5 .

22 Art 6, s 1.

23 Either directly or via the establishment of a branch, subject to (i) the scope of its original authorisation, (ii) the communication of its intention to do so to the competent authorities in its home Member State and (iii) meeting the relevant procedural requirements (Art 34, s 1-3).

24 As defined in Annex II of MiFID (Art 2, s 1). The Directive permits Member States to allow the marketing of securities of AIFs to retail investors within their territory and, for that purpose, to impose requirements on AIFMs and/or AIFs that are stricter than those imposed under the Directive (Art 32, s 1).

25 Again, subject to communicating its intention to do so to the competent authorities in its home Member State (who must then pass the information on to the competent authorities in the applicable host Member States), and meeting the relevant procedural requirements (Art 33, s 1-2).

26 Provided that, inter alia: (i) the Commission has determined that the legislation regarding prudential regulation and ongoing supervision in the relevant third-party country is equivalent to the Directive and effectively enforced; (ii) the third-party jurisdiction has granted EU-domiciled AIFMs reciprocal market access; and (iii) the supervisor of the AIFM has signed a co-operation agreement with the competent authorities of the relevant Member State (Art 39, s 1 and 3). The EU has characterised this phase-in period as necessary to ensure appropriate controls and co-operation agreements are put in place to 
enable regulators to effectively supervise non-EU-domiciled AIFMs (FAQs, supra n 16).

27 Alternatively, the Commission.

28 This includes a prohibition against any undisclosed preferential treatment of investors (Art 9, s 1(a)-(c)).

29 This includes conflicts (i) between an AIFM (including its managers, employees and those able to exercise direct or indirect control) and AIF investors, and (ii) between different AIF investors (Art 10, s 1).

30 Art 10, s 1. This is in fact a purposive interpretation of what, it must be said, is a tortured piece of legislative drafting which contemplates the maintenance of "effective" arrangements "with a view to taking all reasonable steps designed to prevent conflicts of interest" (emphasis added). It remains to be seen how authorities will interpret the interplay between the requirement of effectiveness, the subsequent reasonableness qualifier and the notion that the arrangements need only be "designed" to prevent conflicts of interest.

31 Art $10, \mathrm{~s} 1-2$. This is, once again, a purposive interpretation of an ambiguously drafted provision. Specifically, the Directive contemplates disclosure where an AIFM's conflict arrangements are "not sufficient to ensure, with reasonable confidence, that the risks of damage to investors' interests will be prevented" (emphasis added). However, if one acknowledges that preventing the risk of damage is not the same thing as preventing the damage itself, this language is potentially inconsistent with the "adverse effects" standard articulated in the same Article.

32 Art 11, s 2.

33 Art 11, s 3(a)-(c).

34 Art 11, s 4. The Directive further provides that Member States shall ensure that an AIFM has in place procedures which provide it with access to securities/financial instruments on the date it is required to deliver them pursuant to any short-selling arrangement.

35 Art 12, s 1. As a corollary, an AIFM must ensure that the redemption policy of each AIF it manages is appropriate given the liquidity profile of its portfolio assets (Art 12, s 2).

36 Art 11, s 1.

37 The remuneration requirements do not appear in the most recent draft of the Directive made available by the Commission. However, it is described in the more recent FAQs, and, more broadly, is consistent with the EU's emerging position on remuneration within financial institutions; see http:// ec.europa.eu/internal_market/company/directors-remun/ index en.htm (accessed on 26 January 2011).

38 Art 14.

39 2006/49/EC.

40 Art 9, s 2; Art 10, s 3; Art 11, s 5; Art 12, s 3.

41 Art 16, s 1. Third-party valuators domiciled in jurisdictions outside the EU must be subject to regulatory standards equivalent to those applicable within the EU (Art 37, s 1(b)).

42 Art 16,s 1.

43 Art 17, s 1(a)-(c). Where an AIF is domiciled in a third country, Member States will allow it to delegate the performance of its functions to a sub-depositary in the same third country provided that the legislation of that third country is equivalent to the Directive and effectively enforced (Art 38, s 1). Such sub-depositaries must also, inter alia, be (i) subject to effective prudential regulation and supervision which is equivalent to the relevant EU law, and (ii) domiciled in jurisdictions where co-operation between the home Member State and the relevant authorities of the third country is sufficiently ensured (Art 38, s 1(a)-(c)).

44 Art 17, s 3. An AIFM cannot, however, act as a depositary (Art $17, \mathrm{~s} 2)$.

45 Art 17, s 2 and 5.
46 Including descriptions of (i) the permitted assets and techniques and their attendant risks, (ii) any investment restrictions and (iii) the circumstances in which the AIF may use leverage and the types and sources of permitted leverage (Art 20, s 1).

47 Art 20,s 1.

48 Art 19, s 1-3

49 Art 21, s 3(a).

50 Art 20,s 2 and Art 21, s 2.

51 Art 21, s 1.

52 Art 21, s 2(d)-(e).

53 Art 20, s 3.

54 Arts 26-29. This provision applies to both listed and non-listed companies, and includes the conclusion of an agreement which would allow an acquisition.

55 Art 26, s 1(a)-(b).

56 The nature of the information required will depend on whether the company is listed or non-listed; see Arts 27-28.

57 Art 29

58 The Directive defines leverage broadly so as to encompass any method by which an AIFM increases the exposure of an AIF to a particular investment, whether through borrowing of cash or securities, leverage embedded in derivative positions or any other means (Art 3(1)). The Directive contemplates that the Commission will adopt implementing measures setting limits on the leverage an AIFM can employ taking into account, inter alia, the type of AIF, its investment strategy and sources of leverage (Art 25, s 3).

59 Provided that they are temporary in nature and comply with the Commission's leverage limits (Art 25, s 4).

60 Art 22.

61 Art 22, s 4.

62 An AIFM managing an AIF with high levels of leverage on a systematic basis must disclose to investors (i) the maximum level of leverage which the AIFM may employ as well as the right of reuse of collateral or any guarantee granted under the leveraging arrangement; and (ii) on a quarterly basis, the total amount of leverage employed in the preceding quarter (Art 23).

63 An AIFM must regularly provide to competent authorities information respecting the level of leverage and a breakdown between leverage arising from borrowed cash or securities and that embedded in financial derivatives (Art 24, s 1). This information must include the identity of the five largest sources of borrowed cash or securities for each AIF and the amounts of leverage received (Art 24, s 2).

64 Indeed, if not for the EU's fixation with the problem of adequately defining what constitutes a "hedge fund", I suspect that many of the provisions of the Directive would have been more directly targeted at hedge funds and their managers. It is perhaps revealing in this respect that the consultation paper which preceded the Directive was exclusively focused on the regulation - and definition - of hedge funds: see Commission Services Consultation Paper on Hedge Funds (18 December 2008).

65 P McGuire and K Tsataronis, "Estimating Hedge Fund Leverage",Bank for International Settlements Working Paper No 260 (September 2008). The alternative to direct public oversight at least with respect to hedge funds - is "indirect" (ie market) oversight via these institutions' prime brokerage relationships. However, insofar as it has become common practice within the hedge fund industry to allocate business among multiple prime brokers, these institutions frequently possess information in respect of only a fraction of a fund's overall portfolio; $M$ King and P Maier, "Hedge Funds and Financial Stability: Regulating Prime Brokers will Mitigate Systemic Risks" (2009) 5 Journal of Financial Stability 283, 290; Grabaravicius and Dierick, supra 
n 4, 42, and US Government Accountability Office, "Hedge Funds: Regulators and Market Participants Are Taking Steps to Strengthen Market Discipline, but Continued Attention Is Needed”, Report to Congressional Requesters (January 2008), 7. In this respect, public regulators can be understood as potentially more effective aggregators - if not necessarily analysers - of salient information.

66 Employed primarily within the hedge fund industry, side letters are agreements between a manager and one or more investors which vary the terms of the agreement (typically set out in an offering document) by which other investors agree to invest.

67 PriceWaterhouseCoopers, "Changing Rules: The Regulation, Taxation and Distribution of Hedge Funds Around the Globe" (June 2009), 8.

68 Treasury Letter, supra $\mathrm{n} 11,1$.

69 See FSA Discussion Paper, supra n 10.

70 See Morgan Stanley, Comment Letter in Response to the Commission Services Consultation Paper on Hedge Funds (30 January 2009), 2.

71 German Federal Ministry of Finance, Comment Letter in Response to the Commission Services Consultation Paper on Hedge Funds (30 January 2009), 7 stating: "In Germany the supervisory authority demands high risk management standards for hedge funds, which has in our view proven to be successful".

72 Treasury Letter, supra n 11, 9.

73 The carried interest is a performance fee contingent upon the manager exceeding some pre-set minimum annual rate of return (or "hurdle rate"). In the prototypical case, the manager will be entitled to a fee of $20 \%$ of the amount by which a fund's return exceeds a hurdle rate of between 8 and $8.5 \%$. Payment of the fee is typically subject to a high watermark designed to ensure that the fee is only paid where the fund's cumulative performance has recovered from any previous shortfalls.

74 Agarwal et al have estimated that managerial co-investment accounts for $7.1 \%$ of hedge fund assets, with the median manager owning $2.4 \%$ of the equity in their funds:V Agarwal, N Daniel and N Naik, "Role of Managerial Incentives and Hedge Fund Performance" (2009) 64(5) Journal of Finance $2221,2231$.

75 Ibid; Shadab supra n 11, 267; King and Maier, supra $\mathrm{n}$ 67. The one obvious circumstance in which these incentives might fail to disincentivise excessive risk taking being where a fund is under-performing close to the end of its term (and where, as a result, its manager might be tempted to "shoot for the moon").

76 For a recent restatement of the case for regulatory competition in the field of securities law, see R Romano, "Against Financial Regulation Harmonization: A Comment", Yale Law \& Economics Research Paper No 414 (22 November 2010), available at www.ssrn.com (accessed 26 January 2010).

77 Commission Staff Working Document accompanying the AIFM Proposal (30 April 2009) 2009/576 (Impact Assessment).

78 Ibid, 15-17.

79 The Impact Assessment reveals, for example, that all canvassed jurisdictions (i) have an existing regulatory regime governing hedge funds, (ii) place constraints on distributions of hedge fund securities to retail investors, (iii) require the authorisation of hedge fund managers and (iv) impose capital requirements on hedge fund managers (ibid). Oddly, the Impact Assessment only canvassed seven jurisdictions: the UK, France, Denmark, Luxembourg, Ireland, Italy and Spain.

80 And where, as a result, the manager will be able to inflate its compensation by manipulating asset values around redemption windows.
81 Although, in reality, safekeeping requirements are perhaps best understood as merely shifting the source of these potential risks to custodians.

82 Although there may be an argument for employing depositaries in a narrower capacity as subscription agents.

83 It is also arguably the case that valuation is unnecessary in connection with the issuance of fund securities. This is certainly true at the time of initial closing (at which point the fund is in effect a blind pool and where, as a result, the aggregate value of the issued securities is equal to the subscription proceeds less any expenses accruing at the fund level). While the situation becomes somewhat more complicated where the fund raises capital through any subsequent closings, mechanisms typically exist in respect of such closings to ensure that all investors (both "new" and "old") are treated equally on a retrospective basis.

84 That is to say, there are no periodic redemption windows enabling investors to withdraw money at their discretion. In general, this serves to distinguish hedge funds (which often allow for periodic redemptions) from other alternative investment vehicles.

85 AIFM Proposal, supra n 21, 5.

${ }^{86}$ See Letter from the Director General (2 December 2010), provisionally requesting advice on level 2 implementing measures, available at http://ec.europa.eu/internal market/investment/ alternative investments en.htm\#level2 (accessed on 1 February 2011).

87 See statement available at http://ec.europa.eu/internal market/consultations/2008/hedge funds en.htm (accessed 1 February 2011). The consultation period was cut to a mere eight weeks.

88 There is arguably no single, universally accepted definition of "systemic risk". Andrew Lo, however, provides a useful working definition: "the risk of a broad-based meltdown in the financial system, often realized as a series of correlated defaults among financial institutions, typically banks, that occurs over a short period of time and typically caused by a single major event" (Lo, supra n 12, 3-4).

89 Grabaravicius and Dierick, supra $\mathrm{n} 4$ and 5.

90 A Lo, Hedge Funds: An Analytical Perspective (Princeton University Press, 2008), 302.

91 King and Maier, supra n 67, 286.

92 Ibid.

93 Title IV of the Dodd-Frank Wall Street Reform and Consumer Protection Act, Pub Law No 111-203 (2010) does impose, inter alia, registration, recordkeeping and regulatory reporting requirements on many so-called "private funds" and "private advisers", categories broadly - if not completely analogous to AIFs and AIFMs, respectively. The Dodd-Frank Act also contemplates that the US Federal Reserve can extend its regulatory powers to cover financial institutions which pose a potential threat to financial stability (which might include, for example, large, highly leveraged hedge funds).

94 Thus simultaneously reducing financing risk (for the fund), counterparty credit risk (for the fund's counterparties) and systemic risk (for the rest of us). It is worthwhile noting, however, that all this assumes that what is being constrained is economic leverage (not just, for example, accounting or balance sheet leverage).

95 D Awrey, "The FSA, Integrated Regulation and the Curious Case of OTC Derivatives" (2011) 13(1) University of Pennsylvania Journal of Business Law 101, 153.

96 Whether this marginal incentive will translate into a meaningful migration of business offshore is a complex issue requiring further empirical investigation and which, in any event, resides well beyond the scope of this article. 
97 See "Germany Pushes UK on Hedge Fund Rules", Financial Times 17 March 2010; "UK Suffers Hedge Fund Blow", Financial Times 13 May 2010;"Hedge Fund Rules Defended by French MEP", Financial Times 16 May 2010; "Ministers Push for EU Hedge Fund Rules", Financial Times 17 May 2010; "Haggling Over Legislation is Far From Over", Financial Times 18 May 2010; “Osborne's Pyrrhic Victory”, Wall Street Journal 15 July 2010; and "New Regulations for Hedge Funds", Financial Times 10 October 2010.

98 Indeed, as the quotes from German and French politicians at the outset of this article suggest, Germany and France (along with countries like the Netherlands, Denmark and Sweden) had concerns about the adverse impact of hedge funds and private equity funds on their domestic financial markets (and markets for corporate control) well in advance of the GFC; see Callum McCarthy, "Hedge Funds: What Should be the Regulatory Response?”, speech to the European Money and Finance Forum (6 December 2007).

99 See $\mathrm{n} 37$.

${ }^{100}$ See "The Commission Calls for Action on Commodities and Raw Materials", IP/11/122 (2 February2011). See also "Regulating Commodity Speculation Back in EU Spotlight", Wall Street Journal 2 February 2011. 